\title{
Rastin Group Funding (RGF): A Financial Subsystem of Rastin Banking
}

\author{
Bijan Bidabad \\ B.A., M.Sc., Ph.D., Post-Doc. \\ Professor \\ Economics and Chief Islamic Banking Advisor \\ Bank Melli, Iran \\ E-mail:bijan@bidabad.com
}

\begin{abstract}
Rastin Group Funding (RGF) makes mobilization of limited and determined depositor's resources for a specific project possible and shares depositors in the outcome of the projects with the intent of benefit and via the bank according to Rastin Banking rules. In Rastin Group Funding, after evaluation of the project proposal, and by observing the rules of the PLS Base System or the applied Financial Subsystem defined in Rastin Banking and considering the Rastin Banking Executive Bylaw; bank mobilizes the pre-specified depositors' resources for a specific project; and after receiving necessary collaterals and guarantees allocates them to entrepreneur and performs supervision over the project execution. Bank receives capital management fee by supplying capital management services to depositors.
\end{abstract}

Keywords: Rastin Group Funding, RGF, Rastin Banking, Islamic Banking

\section{Introduction}

Rastin Group Funding (RGF), in action, invites (real/legal) persons to participate in a specific project ${ }^{1}$ of the entrepreneur $^{2}$ to finance a part or all of the needed money resources for execution of the project. Science financing processes needs application of many different technical, financial, economic and legal issues; therefore, without providing necessary conditions for these operations, and without benefiting a sufficient infrastructure to perform these types of operations, there would not be the success to reach the goals of the project and intents of depositors ${ }^{3}$. Rastin Banking ${ }^{4}$ provides a confident and sufficient infrastructure for Musharakah and sponsoring activities. Thus, using this structure, and also the standards, processes, workflow and operations, Rastin Group Funding can be implemented.

Rastin Banking has a modular design, so when the bank desires to develop the operations can activate the corresponding part. Many of instruments, Financial Subsystems ${ }^{5}$, and Complementary Systems ${ }^{6}$ will be used correspondingly when the full system of Rastin Banking is installed. Rastin Group Funding just uses some particular parts of the Rastin Banking infrastructure and operations.

\footnotetext{
1- Project is a collection of economic activities with specified and concrete plan with defined cost and terms for making profit through Rastin PLS banking offered to PLS bank.

${ }^{2}$ - Entrepreneur is a real person or legal entity who proposes a project to PLS bank for financing through PLS banking system and executes the project until the end. In addition to have legal, financial, technical and performance capabilities, the entrepreneur should have the other capabilities and facilities/possibility to carry out the job.

3. Depositor is real person or legal entity with a certain amount of fund (cash) asks PLS bank to participate in Rastin PLS Banking products through direct contact with PLS bank, or via internet and buys Rastin Certificate of one of the PLS banking products.

${ }^{4}$ Rastin PLS banking documents are accessible through: http://www.bidabad.com

5 - Financial Subsystems of Rastin Banking System refer to different defined financing methods and services. These subsystems are governed by Rastin PLS Base System's regulations.

6. Complementary Systems of Rastin Banking refer to different defined compliment innovations, web-systems and other methods and procedures that offer complementary services to facilitate financial operations of the bank.
} 


\section{Rastin PLS Base System and its Financial Subsystems}

Rastin PLS Base system ${ }^{7}$ refers to the main process and general regulations of Rastin Profit and Loss Sharing (PLS) Banking system. On request and on behalf of the depositor ${ }^{8}$, the bank ${ }^{9}$ invests his fund in one of Rastin PLS products and instead, gives Rastin Certificate of the selected project ${ }^{10}$ to him and allocates his fund to the selected project of the entrepreneur; and supervises the implementation and execution of the project. In the end, after deducting its own commission, bank divides the profit/loss (if any) among engaged sides (depositors and entrepreneur). The bank is the agent of the depositor and is responsible for observing his rights (depositor). He must use all his expertise to reach this end. The bank's trustee unit ${ }^{11}$ will supervise the obligations carry out of entrepreneur on behalf of depositor and bank receives a commission for his financial intermediation. In Rastin PLS Base system, Musharakah (Participation) Certificates are used for finite projects ${ }^{12}$, and Pazireh (Subscripted) Certificates are used for infinite projects ${ }^{13}$. These two certificates belong to the category of Rastin Certificates, and activities are done under Rastin Banking regulations. The fixed profit rate is eliminated in Rastin PLS banking, and the return rate is calculated according to the real return of capital in the real economy. Most of the regulations of Rastin PLS Base system are extended to its Financial Subsystems.

To make the bank capable of reaching his goals in a proper way, this system has its own organization, structure, and working process. Major topics in Rastin PLS Base system consist of organizational, professional behavior of assessor ${ }^{14}$ and trustee, project proposal ${ }^{15}$, assessment, guarantees, collaterals and entrepreneur cash contribution (brought), insurance, contract set-out, supervision, entrepreneur ${ }^{16}$, financial transparency, information disclosure, governance, auditing, Rastin Participation Accounting, change of project timing, settlement, bank receipts, transforming Pazireh (Subscripted) Certificates into shares of entrepreneur company, inspection and commodity standard, auxiliary financial tools, unexpected accidents (Force Majeure), arbitration and more ...

Rastin PLS Financial Subsystems refer to specific financing methods or services in Rastin PLS Banking. These subsystems work under general regulations of Rastin PLS Base system, and are:

1. Joalah Financial Sharing (JFS): ${ }^{17}$ is a method in which, the bank finances entrepreneur (producer) from depositor's resources or the provided sources by the buyer; by selling Future Certificates (to depositor or buyer)

\footnotetext{
${ }^{7}$ Bidabad, Bijan, Rastin Profit and Loss Sharing (PLS) Base System. Journal of Islamic Economics, Banking and Finance, 2014. http://www.bidabad.com/doc/pls-base-en.pdf

${ }^{8}$ Depositor is a real or legal person who asks PLS bank to participate his certain amount of fund (cash) in Rastin PLS banking products through direct contact or internet and buys Rastin Certificate of one of the PLS banking products.

${ }^{9}$ In Rastin PLS banking, bank is a unit which allocates resources from depositors to entrepreneur and according to specific contracts the obtained profit or loss is divided between depositor, entrepreneur. By receiving commission (Joalah fee), bank provides capital management services to depositor, and invest his resources according to his choice and in return, delivers Rastin Certificate to him. Bank has to protect depositors' rights by using all his specialized potentialities.

${ }^{10}$ Project is a collection of economic activities with specified and concrete plan with defined cost and term for making profit through Rastin PLS banking offered to PLS bank.

${ }^{11}$ The trustee unit is a unit in Rastin PLS bank for supervision and control of Rastin PLS proposed projects on behalf of bank and regarding good performance of projects in comparison to initial proposal through key indicators and financial reports till final delivery of project.

12 - Finitude projects are those projects that after completion of construction and by starting utilization period are to be consumed from viewpoints of bank and depositor. Finitude projects are not productive in depositor's viewpoint and do not make value added for depositor, although the depositor in utilization period receives his installments for principal or rent of the project.

13 - Infinitude projects are those projects that after completion of construction period and starting utilization period are productive in viewpoints of depositor and entrepreneur, and depositor shares in the yield of the project.

${ }^{14}$ Assessment unit is a unit in PLS department of PLS bank which assesses the competence and capabilities of entrepreneur and his proposal.

${ }^{15}$ Proposal is a written document covering a collection of necessary information about the proposed project of entrepreneur and describes analytical justification of the project from economic, technical and financial points of view, with enclosed necess ary legal licenses and documents which is submitted to Rastin PLS bank by entrepreneur. After evaluation of bank if be approved, the proposal will be a reference document and can be used against entrepreneur executive operations.

${ }^{16}$ Entrepreneur is a real or legal entity who proposes a project to PLS bank for financing through PLS banking system and executes the project until the end. In addition to have legal, financial, technical and performance capabilities, the entrepreneur should have the other capabilities and facilities/possibilities to carry out the job.

${ }^{17}$ Bidabad, Bijan, Joalah Finance Sharing (JFS). Journal of Islamic Economics, Banking and Finance, 2014. http://www.bidabad.com/doc/jfs-paper-en.pdf
} 
and in the framework of another joalah contract, entrepreneur produces the buyer requested commodity. Future Certificate is used in JFS.

2. Mudarabah Financial Sharing (MFS): ${ }^{18}$ is a kind of mudarabah under Rastin PLS banking in which bank introduces the entrepreneur project proposal in the field of trade or transaction of commodities (commerce) to depositors and by selling them Mudarabah Certificates, finances the entrepreneur (modarib). In MFS Mudarabah and Periodic Mudarabah Certificates are used.

3. Installment Financial Sharing (IFS): ${ }^{19}$ in IFS, installer (moghsit or depositor) will finance a portion of the needed fund of an entrepreneur through the bank for a certain period of time (amortization period). The entrepreneur will pay back his share by installments and will own the total property of the project, and IFS ends. IFS can be carried out through one of the contracts of Ordinary Mughasatah (Installment), Rental Mughasatah (installment) and Musharakah (sharing) Mughasatah (installment); and by application of three related kinds of certificates of Ordinary Mughasatah and Rental Mughasatah Certificates for finite projects and Musharakah Mughasatah Certificate for infinite projects.

4. Rent Financial Sharing (RFS): ${ }^{20}$ entrepreneur temporarily donates the ownership of a part of his productive asset $^{21}$, rental asset ${ }^{22}$, or dead asset ${ }^{23}$ to the depositor who finances him but keeps it as a mortgage. Then pays back the fund received from the yields of the asset proportional to depositor's share to depositor at the end of the contract, or periodically. The original deposit of depositor will be given back to him after the end of the project. The profit of the project will be given to depositor periodically or in a lump. Mortgage Sharing, Periodic Mortgage Sharing, Mortgage Mudarabah (commerce), Periodic Mortgage Mudarabah, Mortgage Muzaraah (cultivating), Periodic Muzaraah, Mortgage Mugharasah (planting), Periodic Mortgage Mugharasah, Mortgage Musaghah (irrigation), Periodic Mortgage Musaghah, Mortgage Istisna (industrial/manufacturing), Periodic Mortgage Istisna and Rental Certificates are used in RFS.

5. Bail Financial Sharing (BFS): ${ }^{24}$ is the application of deposit of depositor by an entrepreneur to produce a defined commodity and delivering the commodity or paying back its value in a future specified time. BFS uses Bail Certificate.

6. Rastin Group Funding (RGF): is collecting deposits of specific depositors for a specific beneficial project under the regulations of Rastin Banking. In RGF, Rastin certificate is not issued.

7. Rastin Personal Security (RPS): $:^{25}$ to create competitive conditions and to increase the efficiency of social security insurance and diminishing antitrust of social security systems and pension funds, private and public pension funds are established according to Rastin Banking regulations. People and firms can allocate a portion of their obligatory (or optional) insurance premium payments (for himself or his employees) for social security to the funds that operate under Rastin Personal Security (RPS) and enjoy its benefits. Therefore, they will be exempted from obligatory insurance premium payments equal to the payment they have paid to these funds. RPS uses Social Security Certificate, Personal Security Certificate, and Pension Security Certificates.

8. Rastin Social Takaful (RST) ${ }^{26}$ : benevolent people can deposit their funds at banks for charity purposes, and the bank will be allowed to pay profit (or the principal as well) of deposit to needy people, in the form of a loan or non-returnable payments (according to the depositor request). RST works under Rastin Banking regulations as "public takaful" (humanistic duty of people to resolve others' needs), or "ziman-e-I'alih" (government duty to provide people's livelihood of the society). In addition, the bank can collect Waqf (devoted) deposits to raise fund. Waqf deposit is a kind of deposit devoted by the depositor (benefactor) to the bank, and the bank will use the yields of this deposit to support needy people in the framework of Rastin Banking regulations. Rastin Social

\footnotetext{
${ }^{18}$ Bidabad, Bijan, Mudarabah Financial Sharing (MFS). Journal of Islamic Economics, Banking and Finance, 2014. http://www.bidabad.com/doc/mfs-paper-en.pdf

${ }^{19}$ Bidabad, Bijan, Installment Financial Sharing (IFS). Journal of Islamic Economics, Banking and Finance, 2014. http://www.bidabad.com/doc/ifs-paper-en.pdf

${ }^{20}$ Bidabad, Bijan, Rent Financial Sharing (RFS). Journal of Islamic Economics, Banking and Finance, 2014. http://www.bidabad.com/doc/rfs-paper-en.pdf

21 "Productive assets" refers to the assets of an operating firm.

22 "Rental assets" refers to those assets, which can be let.

23 "Dead assets" refers to non-operating (suspended) firms or uncultivated lands assets.

${ }^{24}$ Bidabad, Bijan, Bail Financial Sharing (BFS). Journal of Islamic Economics, Banking and Finance, 2014. http://www.bidabad.com/doc/bfs-paper-en.pdf

${ }^{25}$ Bidabad, Bijan, Rastin Personal Security (RPS). Journal of Islamic Economics, Banking and Finance, 2014. http://www.bidabad.com/doc/rps-paper-en.pdf

${ }^{26}$ Bidabad, Bijan, Rastin Social Takaful (RST). Journal of Islamic Economics, Banking and Finance, 2014. http://www.bidabad.com/doc/rst-paper-en.pdf
} 
Takaful is applicable by issuing Takaful Certificate and Loan Certificate.

9. Sponsor Crowdfunding (SCF): is the process of collecting non-returnable funds for a specific protective goal of an entrepreneur through the bank via social networks. In SCF, Rastin certificate is not issued.

10. Peer to Peer Loan (PPL): is the process of collecting funds for loan-financing the entrepreneur through the bank and via social networks. In PPL, Rastin certificate is not issued.

11. Rastin Swap Bond (RSB): is based upon Mubadalah (swap) contract between Mobadil (swapper) and Motebadil (swapee) in which the durations and substances of swaps are equal for first and second swaps. Motebadil (swapee) issues the bond and owes to Mobadil equal to the nominal value of the bond, and should pay this amount (badal) to Mobadil (swapper) at maturity. The issuer (Motebadil) is obliged to give the mobaadal for the same amount and period as badal to mobadil. He can choose a combination of amount and period that the multiplication of amount by the period of mobaddal be equal to that of badal. At second maturity, mobadil is committed to returning mobaddal to motebadil. No interest rate is involved in these bonds, and they are of four kinds: Central Bank Rastin Swap Bond, Treasury Rastin Swap Bond, Bank Rastin Swap Bond, and Commercial Rastin Swap Bond. They can be in domestic money or foreign exchange. Regarding the fact that these bonds are not based upon participation and just indicate swapping of assets, is not covered by regulations of the Rastin PLS Base system, but uses its infrastructure such as organization and Rastin Certificate Market.

\section{Rastin Group Funding (RGF)}

In Rastin Group Funding, bank according to the request of specified (limited and determined) depositors mobilizes their resources to be allocated and participated in a specific project under the regulations of Rastin Banking. The entrepreneur can be a real person or legal entity subject to considering the rules of PLS Base System or applied Financial Subsystem. Observing the related rules corresponding to the PLS Base System ${ }^{27}$ and applied Financial Subsystem for the project is obligatory. Bank by observing the rules of Rastin Banking Executive Bylaw ${ }^{28}$ and after evaluation of the project proposal ${ }^{29}$ and without issuing Rastin Certificate ${ }^{30}$ mobilizes the specified depositor's resources for the evaluated project and after receiving necessary guarantees and collaterals allocates them to the entrepreneur and start supervision over the operation of the project.

Bank according to the pre-specified dates in project proposal reduces his wage from the outcome of the project and regarding the type of the applied PLS Base System or Financial Subsystem and the detailed cited services in the contract and considering the rules of Rastin Banking Executive Bylaw returns the whole or part of the capital (deposit) principle to the depositors. The final settlement will be at the end of the participation period or periodically

27- Rastin Profit and Loss Sharing (PLS) is an activity in Rastin Banking based on participation of depositors in investment and economic activities of entrepreneur based on real yield of projects in order to land interest-free banking according to Islamic commandments and ethics.

In Rastin PLS banking, bank is a unit, which allocates resources from depositors to those who look for financing (entrepreneur) and according to specific contracts; the obtained profit or loss is divided between depositor and entrepreneur. By receiving commission $(\mathrm{Jol})$, bank provides capital management services for depositors, and invests their resources according to their choices and in return, provides them by Rastin PLS banking Certificate. Bank has to use all his specialized potentialities to protect depositors' rights.

28 آ

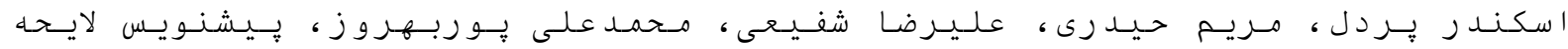

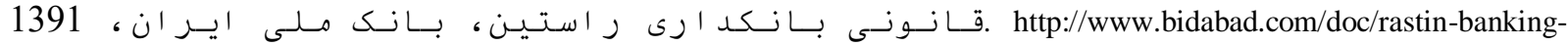
bill.pdf

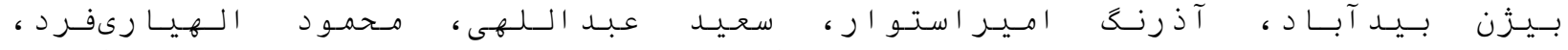

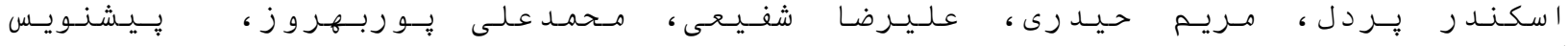

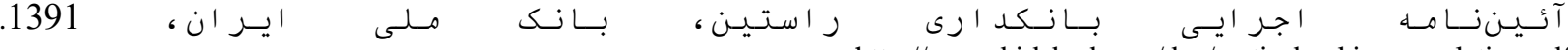
http://www.bidabad.com/doc/rastin-banking-regulation.pdf 29- Project Proposal is a written document covering a collection of necessary information about the proposed project that describes analytical justification of the project from economic, technical and financial points of view, with enclosed necess ary legal licenses and documents; which is submitted to Rastin PLS bank by entrepreneur. After evaluation of the bank if be approved, proposal will be a reference source against entrepreneur executive operations.

30- Rastin Certificates are a collection of certificates designed and issued in the base system and financial subsystems of Rastin PLS banking. Supervisory feature of the trustee unit of the PLS bank on these certificates, distinguishes them from other financial papers and have prefix of "certificate". Being nameless, negotiable in secondary virtual Rastin Certificates Market, having market price based on supply and demand of certificates, settlement by the last certificate holder are some characteristics of Rastin Certificates. Settlement of these certificates are carried out under the supervision of the trustee unit of PLS bank. 
or once in specific times according to the applied PLS Base System or Financial Subsystem.

In Rastin Group Funding, the bank can insert necessary obligations when signing the contract with depositors and entrepreneur. These obligations must not be in conflict with Rastin Banking Executive Bylaw. Bank revenue for evaluation and supervision according to Rastin Banking Executive Bylaw and by considering the other rules and regulations can be increased by half due to supplying better services. However, in all cases, the contents of the rules of the applied PLS Base System or Financial Subsystem are obligatory.

Evaluation of the project proposal must be done by the assessment unit ${ }^{31}$ of the bank either directly or with instrumentality via outsourcing the task of evaluation of the project proposal to other confident assessment corporations or in a special case to real assessors. But the bank can supply a better-quality evaluation of the project proposal due to depositors request and receiving a higher evaluation fee. Supervision over the project execution must also be done by the trustee unit ${ }^{32}$ of the bank either directly or with instrumentality through outsourcing the task of supervision over the project execution to other confident supervision corporations. But the bank can also supply better-quality supervision over the project according to depositors request and receiving higher supervision fee. In all cases, the responsibilities of assessment and supervision are loaded to the bank.

Since in Rastin Group Funding, the relation between depositors and entrepreneur is established via the bank and from the depositor's resources and depositors are aware of the economic and financial condition of entrepreneur, in evaluation of entrepreneur bank dismiss some items of assessments that should be fulfilled in other Financial Subsystems such as: not having returned back cheque and tax settlement certificate relating to previous years entrepreneur's activities. Bank dismisses these items from its evaluation, according to depositor's written agreement. Moreover, public information disclosure of entrepreneur as defined in Rastin Banking Executive Bylaw is restricted to depositors.

\section{References}

بيزن بيدآباد، آذرنى امير استوار، سعيد عبداللهى، محمود الهيارىفرد، اسكندر بردل، مريم حيدرى، عليرضا شفيعى، محمدعلى بوربهروز، بيشنويس

http://www.bidabad.com/doc/rastin-banking-bill.pdf لايحه قانونى بانكدارى راستين، بانكى ملى اير آنير، 1391.

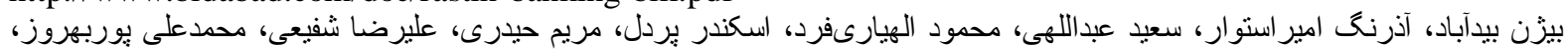

http://www.bidabad.com/doc/rastin-banking-regulation.pdf بيشنويس أينينامه اجر ايى بانكدارى راستين، بانكى ملى ايران، 1391. بيزن بيدآباد، طرح تفصيلى تأمين مالى كرو هى راستين (RGF). اداره كل تحقيقات، برناماريزى و مديريت ريسك، بانكى ملى ايران. 1393. http://www.bidabad.com/doc/detailed-rgf.pdf

Bidabad, Bijan. (2014). New Operational Islamic Banking System, Volume One, Theoretical Foundations, LAP Lambert Academic Publishing, OmniScriptum GmbH \& Co. KG, ISBN: 978-3-659-54463-7.

Bidabad, Bijan. (2014). New Operational Islamic Banking System, Volume Two, Applicational Issues, LAP Lambert Academic Publishing, OmniScriptum GmbH \& Co. KG, ISBN: 978-3-659-55210-6.

Bidabad, Bijan (2018), General Regulatory Framework in Rastin Profit and Loss Sharing Banking (Part IOperational Context). Journal of Business and Finance in Emerging Markets, JBFEM, [S.1.], v. 1, n. 1, p. 1126, May. ISSN 2580-5568. https://doi.org/10.32770/jbfem.vol111-26 http://www.bidabad.com/doc/rastin-regulatory-en-I.pdf

Bidabad, Bijan (2018), General Regulatory Framework in Rastin Profit and Loss Sharing Banking (Part II-Legal Groundwork). Journal of Business and Finance in Emerging Markets, JBFEM, JBFEM, [S.1.], v. 1, n. 2, p. 109-126, Nov. ISSN 2580-5568.

https://doi.org/10.32770/jbfem.vol1109-126

http://www.bidabad.com/doc/rastin-regulatory-en-II.pdf

\footnotetext{
31- Assessment unit is a unit in PLS department of Rastin PLS bank which assesses the competence and capabilities of entrepreneur and his proposal.

32- The trustee unit is a unit at PLS department of Rastin PLS bank for supervision and control of Rastin PLS proposed projects on behalf of bank regarding good performance of project in comparison to initial proposal through key indicators and financial reports and supervision for final delivery of the project.
} 
Bidabad, Bijan (2019), General Regulatory Framework in Rastin Profit and Loss Sharing Banking (Part IIIAuxiliary Provisions). Journal of Business and Finance in Emerging Markets, JBFEM, May, Vol 2, No. 1, pp. 51-65. ISSN 2580-5568.

https://doi.org/10.32770/jbfem.vol251-66

http://www.bidabad.com/doc/rastin-regulatory-en-III.pdf

\section{Copyrights}

Copyright for this article is retained by the author(s), with first publication rights granted to the journal.

This is an open-access article distributed under the terms and conditions of the Creative Commons Attribution license (http://creativecommons.org/licenses/by/4.0/) 